\title{
Thyroid Nodule Inspection as Consideration for Surgery
}

Yuliana

Departmen of Anatomy, Faculty of Medicines, Udayana University, Bali, 80224, Indonesia

Corresponding author: Kerta Bedulu Street Gang V no 23, Sidakarya, Denpasar, Bali, 80224, Indonesia. E-mail addresses: lee.yuliana @ gmail.com.

\begin{tabular}{|c|c|}
\hline article info & Abstract \\
\hline $\begin{array}{l}\text { Article history: } \\
\text { Received: } 17 \text { February } 2018 \\
\text { Received in revised form: } 23 \\
\text { November } 2018 \\
\text { Accepted: } 31 \text { December } 2018 \\
\text { Available online: December } 2018 \\
\\
\text { Keywords: } \\
\text { Thyroid Nodule } \\
\text { Surgery } \\
\text { Size }\end{array}$ & $\begin{array}{l}\text { Thyroid gland is essential in our body metabolism. Sometimes there are nodules on it, } \\
\text { whether on palpation or unexpected finding from an ultrasound test. Based on thyroid } \\
\text { function importance in metabolism, then not all thyroid nodule needs to be operated. This } \\
\text { article aims to know thyroid nodule test for operation consideration. Total thyroidectomy } \\
\text { patients need hormonal thyroid replacement in life. Voice hoarseness and calcium imbalance } \\
\text { metabolism often occur post-thyroidectomy. Therefore, operation indication should be well } \\
\text { determined by considering risks for every patient. We found that only aggressively grown } \\
\text { nodule and cancer need to be operated as soon as possible. Otherwise, it should be observed } \\
\text { routinely every } 6 \text { to } 12 \text { months. } \\
\text { 2018 Scientiae Educatia: Jurnal Pendidikan Sains }\end{array}$ \\
\hline
\end{tabular}

\section{Introduction}

Lumps in the thyroid gland (thyroid nodules) were found in the community. Although it can be seen during palpation (touching) of the neck, it is more often seen through ultrasound (Pemayun, 2016). The size of thyroid nodules was associated with the risk of thyroid cancer. The incidence of thyroid cancer in Indonesia according to GLOBOCAN (Global Cancer Data) 2018 data is 7882 new cases (Frieda, 2018). Thyroid cancer ranks ninth in all cancers in Indonesia (Wiwit et al., 2016). Not all thyroid nodules are thyroid malignancies. Less than 5 percent of thyroid nodules are malignant. Therefore, not all thyroid nodules have to be operated considering the importance of thyroid function in the body's metabolism (Parura et al., 2016).

The thyroid gland is anterior to the trachea. This gland consists of 2 lobes, the right lobe and the left lobe, and middle lobe. This gland usually is not palpable. The thyroid gland produces triiodothyronine and thyroxine hormones to control heart rate, blood pressure, body temperature, and rate of basal metabolism (Nguyen et al., 2015).

Clinical thyroid nodules can be palpated in $4-7 \%$ of adult cases in the United States (Porterfield et al., 2008). Through an ultrasound test, thyroid nodules can be found in about $70 \%$ of adults (Godfarb et al., 2011). In asymptomatic patients, the possibility of fatalities 
underlies the investigation. The results of the fine needle aspiration biology cytology that were false negative were considered in treating patients with thyroid lumps (Hambleton and Kandil, 2013).

Schulte (2009) said that a total anamnesis, accompanied by an examination of TSH and Technetium (Tc) scans, would identify hyper-functional nodules. Determining whether there is a cancer risk from a nodule is a reasonably complicated concept, and the approach includes medical, rational, economic, and cultural considerations. What is vital in dealing with thyroid nodules is the prevention of death and morbidity. Death from thyroid cancer is rare. Small tumors are usually unknown and are often found accidentally on post mortem examinations (Schulte, 2009).

Thyroid cancer is the most common malignancy in the endocrine system, which is around $3.8 \%$ of all cancers in the United States and ranks 9th out of all cancers. In the past three decades, the number of patients diagnosed with thyroid cancer has increased significantly (Davies and Welch, 2014; Weir et al., 2015). This may be due to the increasing use of investigations such as ultrasound, computed tomography (CT Scan), magnetic resonance imaging (MRI), and positron emission tomography scans (PET Scan) that can incidentally detect the presence of thyroid nodules (Nguyen et al., 2015; Ukrainski et al., 2016).

Death from thyroid cancer usually occurs in similar types of anaplastic thyroid carcinoma (Yeung and Habra, 2012). This case arises in as many as 2-5\% of thyroid carcinoma (thyroid cancer). But this type of cancer can cause a mortality rate of up to 50\% (Nguyen and Misra, 2015).

The right time to carry out a test of suspected follicular thyroid cases is unclear, but this is complicated by the fact that delays in diagnosis cause distant metastases through hematogenous spread. For medullary thyroid cancer which is rare, there is evidence to suggest that early detection and treatment will improve results. In the case of anaplastic thyroid cancer, only the initial treatment will enhance the patient's survival (Schulte, 2009).

The purpose of this paper is to know the test of thyroid nodules as consideration for surgery. The earlier the patient can be adequately diagnosed, the better the prognosis will be. Conversely, in cases that do not require surgery, the function of thyroid hormones can be maintained, and patients will not experience surgical complications. 


\section{The Description of Thyroid Nodule in the Test}

Most thyroid lumps are benign (Knox, 2013). Thyroid nodules are cell growth (lumps) in the thyroid gland. It is estimated that around 3-7\% of the world population has a lump in the thyroid gland (Corso, 2014). About 5\% of detected nodules are malignant (Cooper et al., 2010; Lew et al., 2011).

Only nodules larger than $1 \mathrm{~cm}$ are evaluated unless other risk factors increase malignancy. These risk factors include head and neck radiation history, history of thyroid cancer or thyroid disease in the family, adverse ultrasound examination results, lymphadenopathy, history of goiter, female sex, and Asian race (Cooper, 2010).

\subsection{Thyroid Cancer}

The most common type of thyroid cancer is the papillary type. The lifetime risk of developing thyroid cancer is around $1.1 \%$. The 5-year survival rate increased to $97.8 \%$. Nearly $70 \%$ of cases are currently diagnosed when cancer is still localized in the thyroid gland (Nguyen et al., 2015).

Thyroid cancer is more common in women than in men, with a ratio of around 3: 1 and is more common in Asian populations. The age group most often suffering from thyroid cancer is between 45 to 54 years (Nguyen et al., 2015). But the results of research by Kamran et al. in 2012, it turned out that young age and male sex increased the risk (Kamran et al., 2012). Symptoms of thyroid cancer, in general, are painless swelling in front of the neck, difficulty swallowing, difficulty breathing, hoarseness, and changes in sound (Nguyen et al., 2015). Sometimes thyroid cancer patients also experience insomnia, fatigue, and diarrhea (Singer et al., 2011).

Thyroid cancer is grouped into 4 main types, namely (Fitzgerald, 2013; Sipos and Mazzaferri, 2010):

a. Papillary thyroid carcinoma represents $70-80 \%$ of cancers and is at least aggressive because it grows and metastases.

b. Follicular thyroid carcinoma, about $14 \%$ is more aggressive and is associated with iodine deficiency.

c. Medullary thyroid carcinoma, about $3 \%$ and is included in multiple endocrine neoplasias. This type produces a lot of calcitonin and is a very high calcitonin level which is a sign of this cancer. 
d. Anaplastic thyroid carcinoma represents about $2 \%$ of thyroid cancer and is the most malignant because it metastasizes the surrounding lymphatic tissue and distant sites.

\subsection{Kinds of Test for Nodule Thyroid Support}

\subsubsection{Blood Test}

Blood tests needed include TSH (Thyroid Stimulating Hormone) levels. TSH is released from the anterior pituitary and signals the thyroid gland to make thyroid hormones (triiodothyronine / T3 and thyroxine / T4). When thyroid hormone levels are low, TSH increases, and vice versa. If TSH is below average, it means the hyperactivity gland and should be tested for thyroid uptake and scan. If the nodule is hyperfunctional, cytology is not needed. Nodules with normal hormone levels require a Fine Needle Aspiration Biopsy (FNAB) test, because of the risk of malignancy increases. All nodules require ultrasound test. However, the ultrasound test must be combined with blood TSH test and FNAB to get the right conclusions (Cooper et al., 2010).

\subsubsection{Ultrasound Test}

Microcalcification ultrasound is typical for papillary thyroid cancer. Benign nodules (benign) usually have more than 50\% cystic and spongiform features (Cooper et al., 2010). The results of FNA test are often imperfect because around $20-25 \%$ of the samples return with dubious results (Kamran et al., 2013). Increased incidence of thyroid nodules is likely because ultrasound resolution is getting better (Roy et al., 2012; Wang et al., 2011).

\subsubsection{Fine Needle Aspiration Biopsy (FNAB) Test}

FNAB Test is the most accurate, inexpensive, and the best diagnostic method for testing thyroid nodules (Karadeniz et al., 2013). FNAB can be done by palpation alone or guided by ultrasound, especially for cystic nodules, which are posterior or which are difficult to palpate (Nikiforov, 2013). FNAB aims to get at least six follicular cell groups, each of which consists of 10 to 15 cells of 2 different aspirates (Cooper et al., 2010). The sensitivity of FNAB ranges from $65-98 \%$, and its specificity is $72-100 \%$ (Pinchot, 2009). Sometimes FNAB can be done with the help of USG (US-guided FNA) (Robitschek et al., 2010; Seiberling, 2008). False negative FNAB results are often found in nodules larger than $3 \mathrm{~cm}$ because often the samples 
taken are incorrect (Yoon et al., 2011). FNAB cannot be done on nodules that are less than 5 $\mathrm{mm}$ in size because they are often nondiagnostic (Mazzaferri and Sipos, 2008).

If abnormal neck lymph nodes are found, an FNAB test of the lymph node must be performed next to FNAB in the thyroid nodule. The nodules chosen for biopsy are the most non-functional nodules, with the most suspicious features, or the most massive nodules. FNAB results can be categorized as non-diagnostic, malignant, suspected malignancy (50-75\% risk), indeterminate/doubtful or suspicious of neoplasms (20-30\% risk), follicular lesions (5-10\%), and benign (Cooper et al., 2010).

If the results of FNAB (cytology) are benign, no further treatment is needed. However serial ultrasound test needs to be done every 6 to 18 months to monitor nodule growth (Bourret, 2015). If there are more than $50 \%$ changes in volume or more than $20 \%$ increase in size in a minimum of 2 dimensions, with a minimum increase in the size of solid nodules of at least $2 \mathrm{~mm}$, FNAB must be done again (Nixon et al., 2013).

\subsection{Treatment for Nodule Thyroid}

\subsubsection{Surgery}

The American Thyroid Association recommends thyroid lobectomy for patients with suspicious thyroid nodules and total thyroidectomy for tumors measuring $>4 \mathrm{~cm}$ and patients at high risk of malignancy. If the FNAB results are found malignancy, a lobectomy or total thyroidectomy must be performed unless there are diffuse contraindications or metastases (Bomeli et al., 2010).

The choice of surgery for primary tumors is hemithyroidectomy, with or without isthmusectomy; near-total thyroidectomy (maintains $<1 \mathrm{~g}$ of thyroid tissue around the recurrent laryngeal nerve); and total thyroidectomy. Near-total or total thyroidectomy is recommended for the treatment of thyroid cancers measuring $\geq 1.0 \mathrm{~cm}$ to $2.0 \mathrm{~cm}$ (Haugen et al., 2016; Lucchini et al., 2013; Shore and Waghorn, 2011). Lifting the gland entirely reduces the risk of malignancy in the remaining parenchyma (Rudolph et al., 2014).

The most common postoperative complications are hypocalcemia and injury to the recurrent laryngeal nerve (Christou and Mathonnet, 2013). Other complications found after surgery are thyroid hormone imbalance, hypoparathyroidism, bleeding, and infection. Therefore, unnecessary surgery is limited, especially for asymptomatic patients with benign lesions (Cibas and Ali, 2009). 
Sometimes thyroid surgery can be done on an outpatient basis. The critical thing to note is the hematoma that occurs in the first six hours after surgery. Every patient on an outpatient thyroid surgery must be carefully monitored according to medical indications (Khavanin et al., 2014; Terris et al., 2013).

\subsubsection{Radioactive Iodine Therapy}

Radioactive iodine (I131) has an essential role in the treatment of thyroid cancer since 1946 (Vaisman et al., 2011; Wartofsky and Nostrand, 2012). This therapy is used in conjunction with thyroidectomy to ablate the thyroid gland (Valachis and Nearchou, 2013). I131 works by entering thyroid cells through sodium iodide transporters to cause acute cell death (Luster et al., 2008; Schlumberger et al., 2012). Radioactive therapy can increase the 10-year survival rate (10-year survival rate) between 90-95\% (Mallick et al., 2012). Common side effects are salivary gland dysfunction, dry eyes, decreased temporary fertility, transient leucopenia, and thrombocytopenia (Iyer et al., 2011).

\subsubsection{Molecular-Targeted Therapy through Tyrosine Kinase Inhibitors}

Tyrosine kinase inhibitors used are vandetanib, cabozantinib, and sorafenib (Cabanillas et al., 2010). Side effects of vandetanib are diarrhea, skin redness, nausea and hypertension (Wells et al., 2012). Cabozantinib causes side effects of diarrhea, fatigue, hypertension, fistula, respiratory failure, bleeding, sepsis, and sudden death (Elisei et al., 2013). The common side effects of sorafenib are diarrhea, alopecia, skin redness, and arrhythmias (Brose et al., 2014).

\subsection{Prognosis of Thyroid Nodule}

Prognosis of thyroid nodules according to diagnosis and stage of the disease when detected. If detected at the start, the prognosis is good, and life expectancy increases. Conversely if caught late, metastases can occur to other organs that will cause death more quickly.

\section{Conclusion}

Test of thyroid nodules for consideration of surgical procedures requires several diagnostic support tools. Test of TSH, FT3 and FT 4 levels in the blood, ultrasound and fine needle aspiration biopsy is often used in this case. Total thyroidectomy is performed on nodules more 
than $4 \mathrm{~cm}$ in size. In nodules that are less than $1 \mathrm{~cm}$ in size, observation is usually done periodically every 6 to 12 months.

\section{References}

Bomeli SR, LeBeau SO, Ferris RL. (2010). Evaluation of a Thyroid Nodule. Otolaryngol Clin North Am 43(2):229-238. DOI:10.1016/j.otc.2010.01.002.

Bourret JA, (2015). Predictive Models and Technology Present Opportunities to Support Early Diagnosis, Treatment, and Adherence to Guidelines. American Health \& Drug Benefit 8(1):39-40. Available online: https://www.ncbi.nlm.nih.gov/pmc/articles/PMC4415174/

Brose, M. S., Nutting, C. M., Jarzab, B., Elisei, R., Siena, S., Bastholt, L., ... \& Sherman, S. I. (2014). Sorafenib in radioactive iodine-refractory, locally advanced or metastatic differentiated thyroid cancer: a randomised, double-blind, phase 3 trial. The Lancet, 384(9940), 319-328. DOI: 10.1016/S0140-6736(14)60421-9.

Cabanillas, M. E., Waguespack, S. G., Bronstein, Y., Williams, M. D., Feng, L., Hernandez, M., ... \& Busaidy, N. L. (2010). Treatment with tyrosine kinase inhibitors for patients with differentiated thyroid cancer: the MD Anderson experience. The Journal of Clinical Endocrinology \& Metabolism, 95(6), 2588-2595. DOI: 10.1210/jc.2009-1923.

Christou N, Mathonnet M. (2013). Complications after total thyroidectomy. J Visc Surg 150:249-256. DOI: 10.1016/j.jviscsurg.2013.04.003.

Cibas ES, Ali SZ. (2009). The Bethesda System for Reporting Thyroid Cytopathology. Thyroid 19:1159-1165. DOI: 10.1089/thy.2009.0274.

Cooper, D. S., Doherty, G. M., Haugen, B. R., Kloos, R. T., Lee, S. L., Mandel, S. J., ... \& Sherman, S. (2010). Revised American thyroid association management guidelines for patients with thyroid nodules and differentiated thyroid cancer (vol 20, pg 674, 2010). Thyroid, 20(8), 942-942. DOI: 10.1089/thy.2009.0110.

Corso, C., Gomez, X., Sanabria, A., Vega, V., Dominguez, L. C., \& Osorio, C. (2014). Total thyroidectomy versus hemithyroidectomy for patients with follicular neoplasm. A costutility analysis. International Journal of Surgery, 12(8), 837-842. DOI: 10.1016/j.ijsu.2014.07.005.

Davies L, Welch HG. (2014). Current thyroid cancer trends in the United States. JAMA Otolaryngol Head Neck Surg. 40:317-322. DOI: 10.1001/jamaoto.2014.1.

Elisei R, Schlumberger MJ, Muller SP, et al. (2013). Cabozantinib in progressive medullary thyroid cancer. J Clin Oncol 31:3639-3646. DOI: 10.1200/JCO.2012.48.4659.

Fitzgerald PA. (2013). Thyroid cancer. In: Papadakis MA, McPhee SJ, eds. Current Medical Diagnosis \& Treatment 2013. 52nd ed. US: McGraw-Hill Companies. P.1126-1134.

Frieda IP. (2018). Jangan Malas! Yuk Deteksi Dini Kanker Tiroid dengan PERLAHAN. Diunduh dari: www.https://m.detik.com/health/berita-detikhealth/d-4249760/jangan-malasyuk-deteksi-dini -kanker-tiroid-dengan-perlahan. Diakses tanggal 22 November 2018.

Goldfarb M, Gondek S, Solorzano C, Lew JI. (2011)._Surgeon-performed ultrasound can predict benignity in thyroid nodules. Surgery 150:436-441. DOI: 10.1016/j.surg.2011.07.002.

Hambleton, C., \& Kandil, E. (2013). Appropriate and accurate diagnosis of thyroid nodules: a review of thyroid fine-needle aspiration. International journal of clinical and experimental 
medicine, 6(6), 413. Available online: https://www.ncbi.nlm.nih.gov/pmc/articles/ PMC3703111/.

Haugen Bryan, R., AlexanderErik, K., BibleKeith, C., DohertyGerard, M., MandelSusan, J., NikiforovYuri, E., ... \& Ann, S. (2016). 2015 American Thyroid Association management guidelines for adult patients with thyroid nodules and differentiated thyroid cancer: the American Thyroid Association guidelines task force on thyroid nodules and differentiated thyroid cancer. Thyroid 26(1):101-110. DOI: 10.1089/THY.2015.0020.

Iyer, N. G., Morris, L. G., Tuttle, R. M., Shaha, A. R., \& Ganly, I. (2011). Rising incidence of second cancers in patients with low-risk (T1N0) thyroid cancer who receive radioactive iodine therapy. Cancer, 117(19), 4439-4446. DOI: 10.1002/cncr.26070.

Kamran SC, et al. (2013). Thyroid Nodule Size and Prediction of Cancer. J Clin Endocrimol Metab 98(2):564-570. DOI:10.1210/JC.2012-2968.

Karadeniz Cakmak G, Emre AU, Tascilar O, Gultekin FA, Ozdamar SO, Comert M. (2013). Diagnostic adequacy of surgeon-performed ultrasound-guided fine needle aspiration biopsy of thyroid nodules. J Surg Oncol. 107:206-10. DOI: 10.1002/jso.23212.

Khavanin, N., Mlodinow, A., Kim, J. Y., Ver Halen, J. P., \& Samant, S. (2014). Predictors of 30-day readmission after outpatient thyroidectomy: an analysis of the 2011 NSQIP data set. American journal of otolaryngology,35(3), 332-339. DOI: 10.1016/j.amjoto.2014.01.011.

Knox MA. (2013). Thyroid nodules. Am Fam Physician 88:193-196. Available online: https://www.ncbi.nlm.nih.gov/pubmed/?term=Knox+MA.+2013.+Thyroid+nodules.+Am+ Fam+Physician+88\%3A193-196.

Lew JI, Snyder RA, Sanchez YM, Solorzano CC. (2011). Fine needle aspiration of the thyroid: correlation with final histopathology in a surgical series of 797 patients. J Am Coll Surg 213:188-194. DOI:10.1016/j.jamcollsurg.2011.04.029.

Lucchini, R., Monacelli, M., Santoprete, S., Triola, R., Conti, C., Pecoriello, R., ... \& Avenia, S. (2013). Differentiated thyroid tumors: surgical indications. Il Giornale di chirurgia, 34(56), 153. Available online: https://www.ncbi.nlm.nih.gov/pubmed/ ?term=Lucchini+R\%2C+Monacelli+M\%2C+Santoprete+S\%2C+et+al.+2013.+Differentiat ed+thyroid+tumors $\% 3 \mathrm{~A}+$ surgical

Luster, M., Clarke, S. E., Dietlein, M., Lassmann, M., Lind, P., Oyen, W. J. G., ... \& Bombardieri, E. (2008). Guidelines for radioiodine therapy of differentiated thyroid cancer. European journal of nuclear medicine and molecular imaging, 35(10), 1941. DOI: 10.1007/s00259-008-0883-1.

Mallick, U., Harmer, C., Yap, B., Wadsley, J., Clarke, S., Moss, L., ... \& Smellie, J. (2012). Ablation with low-dose radioiodine and thyrotropin alfa in thyroid cancer. New England Journal of Medicine, 366(18), 1674-1685. DOI: 10.1056/NEJMoa1109589.

Mazzaferri EL, Sipos J. (2008). Should all patients with subcentimeter thyroid nodules undergo fine-needle aspiration biopsy and preoperative neck ultrasound to define the extent of tumor invasion? Thyroid18:597-602. DOI: 10.1089/thy.2008.0100.

Nguyen QT, Lee EJ, Huang MG, Park YI, Khullar A, Plodkowski RA. (2015). Diagnosis and Treatment of Patients with Thyroid Cancer. American Health \& Drug Benefit 8(1):30-38. Available online: https://www.ncbi.nlm.nih.gov/pmc/articles/PMC4415174/ 
Nguyen T, Misra S. (2015). Undifferentiated Anaplastic Sarcomatoid Carcinoma of the Thyroid: Is Surgical Resection Worth it? - A Case Report and Review of Literature. Endocrinol Metab Synd 4: 179. DOI:10.4172/2161- 1017.1000179

Nikiforov YE, Yip L, Nikiforova MN. (2013). New strategies in diagnosing cancer in thyroid nodules: impact of molecular markers. Clin Cancer Res 19:2283-2288. DOI: 10.1158/10780432.CCR-12-1253.

Nixon IJ, Ganly I, Shah JP. (2013). Thyroid cancer: surgery for the primary tumor. Oral Oncol. 49:654-658. DOI: 10.1016/j.oraloncology.2013.03.439.

Pemayun TGD. (2016). Current Diagnosis and Management of Thyroid Nodules. Acta Med Indones 48(3):247-257. Available online: https://pdfs. semanticscholar.org /76c5/ f9d30c46bef3c228cf8ce1cd5b0d0d3f97d3.pdf

Pinchot SN, Al-Wagih H, Schaefer S, Sippel R, Chen H. (2009). Accuracy of fine-needle aspiration biopsy for predicting neoplasm or carcinoma in thyroid nodules $4 \mathrm{~cm}$ or larger. Arch Surg. 144:649-655. DOI: : 10.1001/archsurg.2009.116.

Parura Y, Pontoh V, Merung M. (2016). Pola kanker tiroid periode Juli 2013- Juni 2016 di RSUP Prof.Dr.R.D Kandou Manado. Jurnal e-Clinic 4(2):1-6.

Porterfield JR, Grant CS, Dean DS, Thompson GB, Farley DR, Richards ML, Reading CC, Charboneau JW, Vollrath BK, Sebo TJ. (2008). Reliability of benign fine needle aspiration cytology of large thyroid nodules. Surgery 144:963-968. DOI: 10.1016/j.surg.2008.09.006.

Robitschek J, Straub M, Wirtz E, Klem C, Sniezek J. (2010). Diagnostic efficacy of surgeonperformed ultrasound-guided fine needle aspiration: a randomized controlled trial. Otolaryngol Head Neck Surg. 142:306-309. DOI: 10.1016/j.otohns.2009.11.011.

Roy R, Kouniavsky G, Venkat R, Felger EA, Shiue Z, Schneider E, Zeiger MA. (2012). The role of preoperative neck ultrasounds to assess lymph nodes in patients with suspicious or indeterminate thyroid nodules. J Surg Oncol. 105:601-605. DOI: 10.1002/jso.22115.

Rudolph N, Dominguez C, Beaulieu A, et al. (2014). The morbidity of reoperative surgery for recurrent benign nodular goitre: impact of previous unilateral thyroid lobectomy versus subtotal thyroidectomy. J Thyroid Res p.31-8. DOI: 10.1155/2014/231857.

Schlumberger, M., Catargi, B., Borget, I., Deandreis, D., Zerdoud, S., Bridji, B., ... \& Vera, P. (2012). Strategies of radioiodine ablation in patients with low-risk thyroid cancer. New England Journal of Medicine, 366(18), 1663-1673. DOI: 10.1056/NEJMoa1108586.

Schulte KM. (2009). The Assessment of Thyroid Nodules. In: Hubbard J, Inabnet W, Lo CY. Endocrine Surgery 1:17-28. DOI: 10.1007/978-1-84628-881-4_2.

Seiberling KA, Dutra JC, Gunn J. (2008). Ultrasound-guided fine needle aspiration biopsy of thyroid nodules performed in the office. Laryngoscope 118:228-231. Available online: https://www.ncbi.nlm.nih.gov/pubmed/17989576.

Shore S, Waghorn AJW. (2011). Thyroidectomy. Surgery (Oxf) 29:446-450. DOI: https://doi. org/10.1016/j.mpsur.2011.06.014

Singer, Susanne \& Lincke, Thomas \& Gamper, Eva \& Bhaskaran, Krishnan \& Schreiber, Stefan \& Hinz, Andreas \& Schulte, Thomas. (2011). Quality of Life in Patients with Thyroid Cancer Compared with the General Population. Thyroid : official journal of the American Thyroid Association 22(2):117-24. DOI 10.1089/thy.2011.0139.

Sipos JA, Mazzaferri EL. (2010). Thyroid cancer epidemiology and prognostic variables. Clin Oncol ( $R$ Coll Radiol) 22: 395-404. DOI: 10.1016/j.clon.2010.05.004. 
Terris, D. J., Snyder, S., Carneiro-Pla, D., Inabnet III, W. B., Kandil, E., Orloff, L., ... \& Yeh for the American Thyroid Association Surgical Affairs Committee Writing Task Force, M. W. (2013). American Thyroid Association statement on outpatient thyroidectomy. Thyroid, 23(10), 1193-1202. DOI: 10.1089/thy.2013.0049.

Ukrainski MB, Pribitkin EA, Miller JL. (2016). Increasing Incidence of Thyroid Nodules and Thyroid Cancer: Does Increased Detection of a Subclinical Reservoir Justify the Associated Anxiety and Treatment? Clinical Therapeutics 38(4): 976-985. DOI: https://doi.org/10.1016/j.clinthera.2015.07.013.

Vaisman F, Shaha A, Fish S, Tuttle RM. (2011). Initial therapy with either thyroid lobectomy or total thyroidectomy without radioactive iodine remnant ablation is associated with very low rates of structural disease recurrence in properly selected patients with differentiated thyroid cancer. Clin Endocrinol (Oxf) 75:112-119. DOI: 10.1111/j.13652265.2011.04002.x.

Valachis A, Nearchou A. (2013). High versus low radioiodine activity in patients with differentiated thyroid cancer: a meta-analysis. Acta Oncol 52:1055-1061. Available online: https://www.tandfonline.com/doi/full/10.3109/0284186X.2012.742959

Wang CC, Friedman L, Kennedy GC, Wang H, Kebebew E, Steward DL, Zeiger MA, Westra WH, Wang Y, Khanafshar E, Fellegara G, Rosai J, Livolsi V, Lanman RB. (2011). A large multicenter correlation study of thyroid nodule cytopathology and histopathology. Thyroid. 21:243-251. DOI: 10.1089/thy.2010.0243.

Wartofsky L, Van Nostrand D. (2012). Radioiodine treatment of well-differentiated thyroid cancer. Endocrine 42:506-513. Available online: https://www.ncbi.nlm.nih.gov/ pmc/articles/PMC4162434/

Weir, H. K., Thompson, T. D., Soman, A., Møller, B., \& Leadbetter, S. (2015). The past, present, and future of cancer incidence in the United States: 1975 through 2020. Cancer, 121(11), 1827-1837. Available online: https://onlinelibrary.wiley.com/ doi/abs/10.1002/cncr.29258

Wells Jr, S. A., Robinson, B. G., Gagel, R. F., Dralle, H., Fagin, J. A., Santoro, M., ... \& Read, J. (2012). Vandetanib in patients with locally advanced or metastatic medullary thyroid cancer: a randomized, double-blind phase III trial. Journal of clinical oncology, 30(2), 134. Available online: https://www.ncbi.nlm.nih.gov/pmc/articles/PMC3675689/

Wiwit AF, Selvialiany, Welly Z. (2016). Distribusi Keganasan Organ Tiroid Berdasarkan Pemeriksaan Histopatologi di Kota Pekanbaru. JIK 10(2):67-70. Available online: http://jik.fk.unri.ac.id/index.php/jik/article/view/92/0

Yeung SCJ, Habra MA. (2012). Thyroid: Anaplastic (undifferentiated) carcinoma. Atlas Genet Cytogenet Oncol Haematol 16:935-939. Available online: http://documents.irevues.inist.fr/bitstream/handle/2042/48371/07-2012-AnaCarciThyroid ID5069.pdf

Yoon JH, Kwak JY, Moon HJ, Kim MJ, Kim EK. (2011). The diagnostic accuracy of ultrasound-guided fine-needle aspiration biopsy and the sonographic differences between benign and malignant thyroid nodules $3 \mathrm{~cm}$ or larger. Thyroid 21:993-1000. DOI: 10.1089/thy.2010.0458. 